УДК 1 (091): 294.3

DOI 10.35423/2078-8142.2019.1-2.05

\begin{abstract}
А. Ю. Стрелкова, доктор філософських наук, стариий науковий співробітник Інституту філософії імені Г. С. Сковороди НАН Украӥни e-mail: anastasia3141@gmail.com ORCID: https://orcid.org/0000-0002-2859-8425
\end{abstract}

\title{
БУДДИЗМ У ТВОРЧОСТІ НІЦШЕ
}

Статтю присвячено дослідженню звернення Ф. Ніџұе до буддизму. Філософський аналіз його творів здійснюється з точки зору буддійської «філософії порожнечі». Згадки про буддизм присутні у більшості праць мислителя, однак вони мають неоднозначний й суперечливий характер, що було зумовлено відсутністю в буддології другої половини XIX cm. адекватного уявлення про засадниче для буддійської думки поняття - «порожнечу» (иуньята). На прикладі окремих паралелей показано близькість ідей Ніџще $i$ буддизму (замежовість добра $i$ зла, абсолютний пріоритет істинного пізнання, переоиінка всіх иінностей $і$ шунья-вада Нагарджуни та ін.). Висловлюється також припущення про можливість ознайомлення Нічие з текстом "Дгаммапади». Здійснений аналіз дає підстави стверджувати, що Ніџче інтуїтивно передчував майбутні відкриття академічної буддології, причому його розуміння буддизму виявлялося більш адекватним глибинній філософській думиі буддизму (філософії порожнечі), ніж панівний за тієї доби «культ $\mathrm{Hi}$ щุо».

Ключові слова: Ніџуше, буддизм, дзен, порожнеча, шуньята, Німео, Дгаммапада.

У фрагментах нотаток Ф. Ніцше, що збереглися і побачили світ лише після його смерті, є один несподіваний і суперечливий

(C) Стрелкова А. Ю., 2019 
абзац, який змушує ще раз замислитися про зміст філософського вчення Ніцше і його зв'язок з духовними традиціями Сходу й буддизмом, зокрема. Ніцше пише про себе: «3 усіх європейців, що жили та живуть, - Платон, Вольтер, Гете - я маю душу найширшого діапазону. Це залежить від обставин, пов'язаних не так зі мною, як із “сутністю речей”, - я міг би стати Буддою Свропи: що, звісно, було б антиподом індійського (ich könnte der Buddha Europas werden: was freilich ein Gegenstück zum indischen wäre)» [4, c. 727-728] [20].

Що знав Ніцше про буддизм? Що змушувало його ототожнювати себе з Буддою і вважати себе його протилежністю водночас? Попри масштабну традицію дослідження спадщини Ф. Ніцше, одного з найвизначніших мислителів Заходу, цей вимір його думки, будучи недостатньо висвітленим, залишається в тіні, а природа суперечливості його висловлювань щодо цієї традиції залишається незрозумілою. Проблема вивчення цієї складової філософії Ніцше полягає значною мірою у ії міждициплінарності, адже, хоч як парадоксально це звучить, але внаслідок необхідності спеціальної сходознавчої підготовки, це радше завдання для фахівця-буддолога, ніж для дослідника-ніцшезнавця. Цим зумовлений, зокрема, брак подібних праць в українській науці, яка на даний момент власної буддології не має [21].

На Заході дослідженню ідей різних традицій східної філософії у творчості Ніцше присвячено низку праць, серед яких слід окремо відзначити відому збірку статей за редакцією Г. Пріста «Ніцше та азійська думка» (1991) [16], яка набула значного розголосу і привернула інтерес багатьох дослідників до цієї тематики, а також спеціальний випуск «Журналу ніцшезнавчих студій» («Journal of Nietzsche Studies», вип. 28, 2004 р.), який, у продовження цієї ініціативи, теж був присвячений «вивченню думки Нiцше крізь множинні призми компаративної, або кросс-культурної, філософії» [12, с. 1]. У цілому ж спеціальне дослідження буддійських мотивів у творчості Ніцше почалося порівняно нещодавно: 
йдеться насамперед про праці Ф. Містрі (1981) [13], Р. Г. Моррісона (1997) [14], А. Панаіоті (2014) [18], а також публікації А. Беньяміна [10], А. Браака [11] та інших фахівців, дослідження яких теж зосереджено власне на буддологічному матеріалі.

У цьому дослідженні ми спиратимемося, насамперед, на першоджерела: повне зібрання творів Ф. Ніцше німецькою мовою [17] та тексти буддійського канону (в палійській та китайській версіi) [19; 3]. Якщо твори німецького філософа представлені достатньою для наших потреб мірою в українських та російських перекладах [22], то буддійський канон, за поодинокими винятками, українською мовою (з мови оригіналу) ще не перекладався, й тому ми будемо посилатись переважно на власні переклади і дослідження [9].

У творах Ніцше, починаючи з певного періоду з'являються перші згадки про буддизм і вже не зникають зі сторінок його книг та нотатників. I хоча ми не знайдемо між них розлогих буддологічних відступів, тим не менш, постійна їх присутність і концептуальна гострота їх змісту свідчать про стійкий особистий інтерес Ніцше до філософії буддизму, присутній завжди між рядками його текстів, так би мовити «у фоновому режимі». Однак час від часу ми є свідками того, як цей інтерес виринає на поверхню у явному, вербалізованому вигляді, коли Ніцше безпосередньо говорить про «Будду» («Buddha»), «буддизм» («Buddhismus»), «буддистів» («Buddhist»), паралельно вживає прикметник «буддійський» («buddhistisch») та наразі застарілий його варіант «буддаїстський» («buddhaistisch»). Значна частина цих згадок походить 3 нотаток Ніцше. Однак, згадки про Будду чи буддизм подибуємо й у більшості його друкованих творів.

Найбільше їх у таких працях, як: «Der Antichrist» («Антихрист», 16 випадків: зокрема пункти 20-22, а також кінець і початок пункту 23 цілковито присвячено буддизму), «Zur Genealogie der Moral» («До генеалогії моралі», 10 випадків), «Die fröhliche Wissenschaft» («Весела наука», 8 випадків), «Jenseits von Gut und 
Böse» («За межами добра і зла», 3 випадки), у книзі «Der Wille zur Macht» («Воля до влади», 41 випадок). Поодинокі згадки про буддизм $€$ навіть у «Народженні трагедіï» («Die Geburt der Tragödie», 1872) та у нотатках Ніцше часів написання цього твору, тобто в одній з найбільш ранніх з його значних праць.

Ніцше обізнаний також 3 деякими буддійськими термінами, такими як, приміром, нірвана, а отже, насправді відсилок до буддизму у мислителя набагато більше. Але і це ще не все, адже важлива не лише «літера», а й «дух» написаного Ніцше, адже його «Так казав Заратустра» просякнутий ідеями, напрочуд близькими буддійській філософії, попри те, що на відміну від багатьох інших творів, експліцитно буддизм там взагалі жодного разу не згадується.

Один з найдовших «буддологічних» уривків ми подибуємо в «Антихристі», який за первинним задумом автора мав бути першою книгою «Волі до влади». Зіставляючи буддизм і християнство, він говорить (№ 20): «Обидві [релігії - християнство і буддизм. - A. C.] належать до нігілістичних релігій, як релігії décadence, й обидві напрочуд несхожі одна на одну ... Буддизм у сто разів реальніше за християнство, - він являє собою спадок об'єктивної й холодної постановки проблеми, він з'являється після філософського руху, що тривав сотні років; з поняттям "Бог" вже було покінчено, коли він з'явився. Буддизм є єдиною істинно позитивістською релігією, що трапляється в історії...» [5, с. 645] (український переклад з німецької див.: [8, с. 347-348]).

Цей уривок, знов таки, виразно свідчить про принципово суперечливе і неоднозначне ставлення Ніцше до буддизму. У межах одного абзацу Ніцше висловлює дві протилежні думки: $з$ одного боку, буддизм, разом з християнством, належить до «нігілістичних» релігій, а з іншого - він $є$ «єдиною істинно позитивістською» релігією в історії людства. У першому випадку ставлення Ніцше до буддизму є виразно негативним, а у другому, цілком навпаки, надзвичайно позитивним. Чим же пояснюється така не- 
однозначність і яким було справжнє ставлення Ніцше до буддизмy?

Європа часів Ніцше лише починала знайомитися 3 буддизмом. Сам Ніцше дізнавався про буддизм у 70-80 pp. ХІХ ст., читаючи праці таких дослідників, як П. Дойсен (який до того ж був його близьким другом) та Г. Ольденберг, а також, значною мірою, завдяки інтересу до буддизму з боку Шопенгауера, під впливом i крізь призму ідей якого Ніцше зацікавився східною думкою. До того ж, як вважають дослідники, Ніцше, цілком імовірно, міг знати санскрит, яким він міг оволодіти у 1865-1868 роках під час навчання у Ляйпцизі у першого вчителя М. Мюллера (1823-1900), Германа Брокгауза (1806-1877), і бути, таким чином, чи не найобізнанішим у царині буддизму представником тогочасної Свропи $[10$, c. 673$]$.

Утім, як вважають дослідники, знання Ніцше про буддизм обмежувалися раннім буддизмом [11, с. 2] й, до того ж, у його нігілістичній інтерпретації, яка отримала в науковій історіографії властиву назву «культу ніщо» - це була історично перша спроба інтерпретації вчення буддизму у західній науці, i саме вона була панівною за часів Ніцше. Тож невдивовижу, що у його творах терміни «буддизм», «ніщо», «нігілізм» і «нірвана», яка є найвищою метою буддизму, згадуються майже весь час у парі, формуючи в нашій уяві образ суто нігілістичної релігії, метою якої є розчинення у таємничому, потойбічному, неживому Ніщо.

Однак нігілістична інтерпретація буддизму європейськими вченими була помилковою й зумовленою неправильним розумінням центральної філософії буддизму - філософії «порожнечі» (шуньята), яку спочатку витлумачували як повне знищення, анігіляцію, буквально «ніщо» («nothing», «nothingness»), ототожнюючи 3 ним також буддійську нірвану. Подальші дослідження вказали на цю помилку і виправили ії. Однак це відбулося вже після смерті Ніцше.

Утім, Ніцше «знав» про буддизм більше, ніж було відомо за його життя. Гостре екзистенційне лезо його власної філософії на86

Institute of Philosophy of H. S. Skovoroda of NAS of Ukraine 
ділило його здатністю інтуїтивно наблизитися й «вскрити» ще заховані від тогочасного «академічного ока» глибини буддійської думки, спираючись лише на надзвичайно неповні й часто-густо викривлені дзеркалом доби відомості, що були у його розпорядженні.

Так, одна $з$ добре відомих нам праць Ніцше у дійсності має напрочуд буддійську (або, навіть, дзен-буддійську) назву «Jenseits von Gut und Böse» («По той бік добра і зла»). В «Антихристі» ж він писатиме про буддизм так: «він [буддизм. - A. C.] не говорить: "боротьба проти гріха", але, з повним визнанням дійсності, він говорить: "боротьба проти страждання". Самообман моральних понять він залишає вже позаду себе, - i в цьому його глибока відмінність від християнства - він стоїть, висловлюючись моєю мовою, по той бік добра і зла (jenseits von Gut und Böse $[17$, т. 17,189$]) »[5$, с. 645$]$.

I Ніцше не помиляється. Адже в буддизмі добро і зло (так само, як і страждання), якщо їх розглядають на найглибшому філософському рівні, насправді виявляються насамперед не етичними, а онтологічними категоріями [9, с. 262-272]. Заломлюючись крізь призму буддійської філософії порожнечі (шуньята), категорії моралі перестають бути самостійними й самоцінними сутностями - відбувається їх зняття, але не знищення: прорив до їх справжньої реальності, яка лежить за межами людських конвенцій і не залежить від них. I тому тут стають можливими такі висловлювання, як: «неподвійність добра і зла» (善惡不二), «добро не отримує віддяки», 善不受報, або ж дзенський вислів «не думай про добро і зло» (不思善惡).

I добро, i зло, i рай, i пекло в буддизмі однаково належать до світу сансари, яка є протилежністю нірвани - єдиної царини спасіння: сфери, де більше немає страждання. Як сказано в «Трактаті про серединність» Нагарджуни: «Усі живі створіння перенароджуються відповідно до [своєї] карми: ті, хто чинять погано - у 
пеклі, ті, хто чинять добре - на небі, ті, хто практикують, досягають нірвани

(一切衆生皆隨業而生。惡者入地獄。修福者生天。行道者得涅 槃。 $[3,21]) »$.

Істинне пізнання (просвітлення або нірвана) є головною метою і для буддиста, і для Ф. Ніцше. Будь-які цінності виявляються лише шкідливою умовністю, якщо вони не слугують досягненню цієї мети. Для Ніцше - християнство, Бог, для буддиста - Дгарма Будди, нірвана нічого не варті, якщо вони більше не є справжніми, подібно до фальшивої монети, несправжність якої викрито, хоч яким би значним був їі номінал. Адже шунья-вада («вчення про порожнечу») Нагарджуни, засновника першої філософської школи буддизму Великої Колісниці (магаяни) стверджувала, що все, що встановлюється відносно чогось іншого або виникає з чогось іншого (чи то реальні речі, чи поняття) є неістинним (иунья, «порожнім»), оскільки є залежним, зумовленим чимось зовнішнім, і отже, не має власного, самостійного існування. Тому страждання $є$ атрибутом світу зумовленості (сансари). У такому світі не може бути свободи. Сутри праджня-параміти (перші сутри магаяни) виголошують, що єдиною реальністю, яку не обпікає вогонь у палаючому будинку сансари $є$ «порожнеча», осмислена тепер у позитивному розумінні як нічим необмежений абсолютний простір мислення (акаша). Ніцше так само прагне 3 пасивного світу зумовленості і страждання до активного світу свободи - це своє прагнення він називає «волею до влади» (der Wille zur Macht).

На жаль, маганські сутри в цілому, i, зокрема, «філософія порожнечі» сутр праджняпараміти та Нагарджуни у XIX ст. ще не були предметом дослідження буддологів, які у цей період зосередили свою увагу майже виключно на вченні раннього буддизму, який вважали найближчою до самого Будди, і отже, найдостовірнішою формою буддизму. Таким чином, Ніцше навряд мав уявлення про вчення Нагарджуни. Тим більше, він не міг чути славетного і шокуючого заклику чаньського наставника Лінь-цзі «зустрінеш Будду - вбий Будду», який міг би належати і його Зара88

Institute of Philosophy of H. S. Skovoroda of NAS of Ukraine 
тустрі, і який так нагадує його власне гасло, яке зловісною хмарою нависло над християнським світом: «Бог помер» (Gott ist todt). Утім, виголошуючи «смерть Бога», Ніцше лише виконував одну 3 найважливіших заповідей християнства: «не створи собі кумира», так само, як і шаленець Лінь-цзі лише продовжував головну філософську думку Будди: «усе є порожнім».

Тож Ніцше навіть не уявляв собі, наскільки близько він сам у своїх філософських шуканнях підійшов до найважливіших ідей буддизму.

Але повертаючись до вислову «по той бік добра і зла», зауважимо, що, буддизм не був би буддизмом, якби його засадничі принципи не були присутні відпочатку в самому вченні його засновника Будди Шак'ямуні. I, справді, якщо ми відкриємо палійський канон раннього буддизму, то знайдемо такі рядки («Дгаммапада», вірш № 39):

«Anavassutacittassa ananavāhatacetaso

Puññapāpapahīṇassa natthi jāgarato bhayami [19].

У непорочній думці, у несполоханій думці, що відмовилася від добра і зла, у тій, що не спить, немає страху» [1, с. 65].

Перший на Заході переклад «Дгаммапади» було здійснено у 1855 р. копенгагенським вченим В. Фаусбелем (V. Fausböll, 18211908) латиною [23]. Невдовзі, у 1870 р., свій класичний англомовний переклад публікує М. Мюллер, а наприкінці ХІХ ст. таких перекладів вже декілька: C. Біла (S. Beal, 1878), Дж. Грея (J. Gray, 1881), В. Рокгіла (W. Rockhill, 1883), П. Каруса (Р. Carus, 1894), котрий промовисто назвав свій збірник перекладів, що його ядром була «Дгаммапада», «Свангелієм від Будди» («The Gospel of Buddha»). Тож, хоча ми і не маємо прямих свідчень цього, але не можемо виключати, що ці рядки 3 «Дгаммапади», яка є однією 3 найвизначніших пам'яток буддійської літератури, були відомі i самому Ніцше, особливо, якщо пригадати те, що Ніцше, як ми вже відзначали, невдовзі перед цим (у 2-й половині 60-х років 
XIX ст.) навчався у Германа Брокгауза, який був також і першим вчителем М. Мюллера.

У цій статті ми зупинилися лише на кількох прикладах паралелей між ідеями Ніцше та буддійською думкою. Висвітлення решти вимагає охоплення усього доступного в зібранні творів Нiцше матеріалу, а отже, й окремого розлогого дослідження. Тут же ми можемо лише побіжно згадати деякі з найвиразніших паралелей: «вічне повернення» і круговерть сансари, Заратустра та ідеал бодгісаттви в буддизмі магаяни, негативне ставлення Ніцше до уявлення про душу та буддійське вчення про анатман («відсуність я»), три стадії трансформації людського духу (верблюд - лев - дитина) у «Так казав Заратустра» і три рівні буддійської філософії порожнечі (речей, понять та свідомості) [9], «надлюдина» та будда тощо.

Особливо яскраво простежуються паралелі з дзенбуддизмом: відсутність остаточної мети в дзен і постійне самоперевершення у Ніцше, можливість досягнення найвищої мети (просвітлення), не виходячи за межі звичайного феноменального світу, наголос на практиці, відкидання авторитетів, принцип неприв'язаності, неприпустимість страху та зупинки як необхідні умови істинного пізнання та буття людини у світі тощо.

Таким чином, можна впевнено стверджувати, що вплив буддизму на Ніцше був беззаперечним і значним. Більше того, саме тут шукав Ніцше свій ідеал. Геній Ніцше як мислителя дивовижної екзистенційної глибини дав йому змогу, не маючи у своєму розпорядженні достатніх відомостей для формування адекватного уявлення про буддійську філософію, й більше того, всупереч панівному у його часи погляду на буддизм як на «культ Ніщо», й попри потужний вплив песимістичної рецепції буддизму з боку його духовного вчителя А. Шопенгауера, за «нігілістичною релігією» розгледіти зовсім не Ніщо, а бездонну глибину «порожнечі» самого буття, яка $\epsilon$ справжнім, невичерпним джерелом життя.

Ніцше тим не менш «передчував» майбутні відкриття буддологів, виходячи із сутності цього вчення, яку він талановито 90

Institute of Philosophy of H. S. Skovoroda of NAS of Ukraine 
вхопив за допомогою свого «транс'європейського ока». Цим, власне, і пояснюється суперечливість висловлювань Ніцше про буддизм, з якою ми стикаємося у його працях.

\section{ЛІТЕРАТУРА ТА ПРИМІТКИ}

1. Дхаммапада / пер. с пали, введ. и коммент. В. Н. Топорова. М., 1960. $160 \mathrm{c}$.

2. Лютий Т. В. Українське ніцшеанство // Наукові записки НаУКМА. Т. 115. Філософія та релігієзнавство. К. : ВПЦ НаУКМА, 2011. - C. 60-66.

3. Нагарджуна 龍樹菩薩. Чжун лунь中論 (санскр. Mūlam?dhyamaka-kārikā) // ТСД Т. 30. № 1564. C. 1-39.

4. Нищше Ф. Злая мудрость. Афоризмы и изречения // Нищше Ф. Сочинения. Т. 1. М. : Мысль, 1996. С. 720-768.

5. Нищще Ф. Антихрист. Проклятие христианству // Нищще Ф. Сочинения. В 2 т. Т. 2. - М. : Мысль, 1996. С. 631-692.

6. Ніџше Ф. Повне зібрання творів: критично-наукове видання: У 15 т. - Л. : Астролябія, 2004. 770 с.

7. Нищше Ф. Полное собрание сочинений. В 13 тт. М.: Культурная революция, 2005-2014. Т. 1/1 : Рождение трагедии. Из наследия 1869-1873 гг. / пер. с нем. В. Бакусева, Л. Завалишиной. 2012. $416 \mathrm{c}$.

8. Ніџще Ф. Так казав Заратустра. Жадання влади. К. : Основи, Дніпро, 1993. 415 с.

9. Стрелкова А. Ю. Буддизм: філософія порожнечі. - К. : Видавничий дім «Києво-Могилянська академія», 2015. 408 с.

10. Benjamin A. E. Nietzsche and Buddhism // Journal of the History of Ideas. 1983. Vol. 44. No. 4. P. 671-686.

11. Braak A. Zen and Zarathustra Self-Overcoming without a Self // Journal of Nietzsche Studies. 2015. Vol. 46. No. 1. P. 2-11.

12. Groff S. P. Editorial Foreword // The Journal of Nietzsche Studies. 2004. Vol. 28. P. 1-2.

13. Mistry F. Nietzsche and Buddhism: prolegomenon to a comparative study. Berlin, New York : W. de Gruyter, 1981. 211 p. 
14. Morrison, R. G. Nietzsche and Buddhism: A Study in Nihilism and Ironic Affinities. New York: Oxford University Press, 1997. x, $250 \mathrm{p}$.

15. Nachgelassene Fragmente. November 1882 - Februar 1883 (NF1882, 4[2]). URL: nietzschesource.org

16. Nietzsche and Asian Thought / Graham Parkes, ed. - Chicago and London : University of Chicago Press, 1991. 253 p.

17. Nietzsche F. Gesammelte Werke. 23 Bde. München : Musarion Verlag, 1920-1929.

18. Panaïoti A. Nietzsche and Buddhist Philosophy. New York: Cambridge University Press, 2014. xiv, 244 p.

19. Sri Lanka Tripitaka Project. URL: www.accesstoinsight.org/ tipitaka/sltp

20. Цей афоризм міститься під № 44 у збірці «Böse Weisheit: Aphorismen und Sprüche», яку було перекладено російською i видано у двотомнику серії «Філософська спадщина». Німецький оригінал подаємо за електронним виданням зібрання творів Ніцше німецькою мовою під редакцією Дж. Коллі та М. Монтінарі [15]; перший том цього видання в 2004 р. було перекладено українською [6].

21. Докладніше про вивчення та переклад спадщини Ніцше в Україні див. у статті ніцшезнавця Т. Лютого [2].

22. Впродовж 2005-2014 рр. російською мовою було видано повне видання творів Ніцше [7].

23. Слід відзначити, що ще раніше, у 1840 р., у м. Коломбо в місцевому журналі «The Friend» Деніел Годжерлі опубліував свій переклад 255 віршів «Дгаммапади» англійською мовою, але цей переклад був неповним («Дгаммапада» складається 3423 віршів).

\section{REFERENCES}

1. Dhammapada. (1960). V. N. Toporov (Transl.). Moscow. [In Russian].

2. Lyutyy, T. V. (2011). Ukrainian Nietzsche Studies. Naukovi zapysky NaUKMA. Filosofiya ta relihiyeznavstvo (NaUKMA Research Papers. Philosophy and Religious Studies), 115, 60-66. [In Ukrainian]. 
3. Nagarjuna 龍樹菩薩. Zhong lun中論 (Sanskr. Mūlamadhyamakakārikā). TSD, Vol. 30, No. 1564, 1-39.

4. Nietzsche, F. (1996). Evel Wisdom. Aphorisms and Sayings. In Works. Vol. 1 (pp. 720-768). Moscow: Thought. [In Russian].

5. Nietzsche, F. (1996). The Antichrist. Curse on Christianity. In Works. In 2 vol. Vol. 2 (pp. 631-692). Moscow: Thought. [In Russian].

6. Nietzsche, F. (2004). Complete Works: Critical Scientific Edition: In 15 vols. G. Colli \& M. Montinari (Eds.). L'viv: Astrolabe. [In Ukrainian].

7. Nietzsche, F. (2012). The Birth of Tragedy. From works of 18691873. Vol. 1/1. V. Bakusev \& L. Zavalishyna (Transl.). Complete Works: In 13 volumes. Moscow: Cultural Revolution. [In Russian].

8. Nietzsche, F. (1993). Thus Spoke Zarathustra. The Will to Power. Kyiv: Foundations. [In Ukrainian].

9. Strelkova, A. Yu. (2015). Buddhism: Philosophy of Emptiness. Kyiv: Kyiv-Mohyla Academy Publishing House. [In Ukrainian].

10. Benjamin, A. E. (1983). Nietzsche and Buddhism. Journal of the History of Ideas, Vol. 44. No. 4, 671-686.

11. Braak, A. (2015). Zen and Zarathustra Self-Overcoming without a Self. Journal of Nietzsche Studies, Vol. 46, No. 1, 2-11.

12. Groff, S. P. (2004). Editorial Foreword. The Journal of Nietzsche Studies, 28, 1-2.

13. Mistry, F. (1981). Nietzsche and Buddhism: prolegomenon to a comparative study. Berlin, New York: W. de Gruyter.

14. Morrison, R. G. (1997). Nietzsche and Buddhism: A Study in Nihilism and Ironic Affinities. New York: Oxford University Press.

15. Nachgelassene Fragmente. (1882, November - 1883, Februar). Retrieved from nietzschesource.org

16. Nietzsche and Asian Thought. (1991). Chicago and London: University of Chicago Press.

17. Nietzsche, F. (1920-1929). Gesammelte Werke. München: Musarion Verlag.

18. Panaïoti, A. (2014). Nietzsche and Buddhist Philosophy. New York: Cambridge University Press.

19. Sri Lanka Tripitaka Project. Retrieved from www.accesstoinsight. org/tipitaka/sltp 


\section{Anastasiya Strelkova}

Doctor of Sciences in Philosophy, Senior Researcher H.Skovoroda Institute of Philosophy of the NAS of Ukraine, e-mail: anastasia3141@gmail.com ORCID: https://orcid.org/0000-0002-2859-8425

\section{Buddhism in Nietzche's Works}

\section{Abstract}

This article represents a study of F. Nietzsche's reception of Buddhism. His works are analyzed from the standpoint of the «philosophy of emptiness». Buddhism is mentioned in majority of his works, but these mentions are of ambiguous and contradictory character caused by the lack in the Buddhist studies of the 2nd half of 19th century of an adequate interpretation of the basic concept of Buddhist thought - «emptiness» (sunyata). On the example of several parallels it is demonstrated that there is considerable closeness between the Nietzsche's ideas and Buddhism and a suggestion is made concerning the Nietzsche's acquaintance with Dhammapada. In Nietzsche's works, starting with a certain period, the first references to Buddhism appear and disappear from the pages of his books and notebooks. Nietzsche is also aware of some Buddhist terms, such as, for example, nirvana, and thus, in fact, the reference to Buddhist thinking is much greater. But it proves that not only the letter but also the "spirit" of Nietzsche is important, because his "So Zarathustra said" is imbued with ideas that are very close to Buddhist philosophy, despite the fact that, unlike many other works, explicitly Buddhism does not exist at all never mentioned. True cognition (enlightenment or nirvana) is the primary purpose for both Buddhists and F. Nietzsche. Particularly striking are the parallels with Zen Buddhism: the absence of a final goal in Zen and constant selfimprovement in Nietzsche, the possibility of achieving the highest goal (enlightenment), without going beyond the ordinary phenomenal world, emphasis on practice, rejection of authority, principle of non-commitment, and principle of non-commitment. as the necessary conditions for true knowledge and being human in the world, etc. The analysis presented in this article allows to assert that Nietzsche had intuitionally predicted the future discoveries of academic Buddhology and his understanding of Buddhism resulted much more adequate to the inner essence of Buddhism (philosophy of emptiness) than the prevailing in that historical period «cult of Nothingness». 
Keywords: Nietzsche, Buddhism, zen, emptiness, sunyata, Nothingness, Dhammapada

\section{Анастасия Стрелкова}

доктор философских наук, старший научный сотрудник Института философии имени Г. С. Сковороды НАН Украинь, e-mail: anastasia3141@gmail.com

ORCID: https://orcid.org/0000-0002-2859-8425

\section{Буддизм в творчестве Ницие}

\section{Аннотация}

Статья посвящена исследованию обращения Ф. Нищще к буддизму. Философский анализ его произведений осуществляется с точки зрения буддийской «философии пустотьл». Упоминания о буддизме присутствуют в большинстве работ мыслителя, однако они имеют неоднозначный и противоречивый характер, что было обусловлено отсутствием в буддологии второй половины ХІХ в. адекватного представления об основополагающим для буддийской мысли понятии - «пустотьл» (шуньята). На примере отдельных параллелей показана близость идей Ницие и буддизма (абсолютный приоритет истинного познания, переоценка всех иенностей и шунья-вада Натарджуны и др.). Высказывается также предположение о возможности ознакомления Ницше с текстом "Дгаммапады». Проведенный анализ дает основания утверждать, что Ницие интуитивно предчувствовал будущие открытия академической буддологии, причем его понимание буддизма оказалось более адекватным глубинной философской мысли буддизма (философии пустоты), чем господствующий в ту эпоху «культ Ничmo».

Ключевые слова: Ницие, буддизм, дзен, пустота, иуньята, Ничто, Дгаммапада. 